\title{
Gene therapy and its applicability in Dentistry
}

\section{Terapia gênica e sua aplicabilidade na Odontologia}

\author{
Régida BATISTA ${ }^{1}$ iD 0000-0003-3912-2534 \\ Caio ARRUDA ${ }^{1}$ iD 0000-0002-8759-802X \\ Yuri TAVARES ${ }^{1}$ iD 0000-0002-0323-2654 \\ Thales FREITAS ${ }^{1}$ iD 0000-0002-8700-1983 \\ Thiago ARAÚJO² (iD) 0000-0002-1185-7902 \\ Adriano RAMOS ${ }^{1}$ iD 0000-0001-5896-4513
}

\begin{abstract}
Objective: Explore scientific publications on the use of gene therapy in dentistry. Methods: A bibliographic survey was carried out with articles published in the last eleven years, available on online platforms that had the highest correlation to the proposed theme. Results: Since the 1960s, researchers have attempted to establish guidelines for treatments using gene therapy; however, it was only in the mid-1990s that their use in science was authorized. Gene therapy in dentistry has the ability to alter and improve genetically, through stem cells in dental tissues associated with recombinant viral vectors, therapeutic protocols against diseases that do not respond to conventional treatments. Conclusion: The perspectives of dentistry concerning this resource have been positive, mainly in the reestablishment and regeneration of tissues in pulp pathologies, periodontopathies, bone disorders, orofacial pain among others. It is known that this form of therapy still requires more research, however, in the near future, it may be a safe first option treatment in hospital and outpatient settings.
\end{abstract}

Indexing terms: Dental Care. Dentistry. Genetic therapy.

\section{RESUMO}

Objetivo: Explorar publicações cientificas acerca do uso da terapia gênica na Odontologia. Métodos: Foi realizado um levantamento bibliográfico com artigos dos últimos dez anos disponíveis em plataformas online que continham maior correlação com o tema proposto. Resultados: Desde os anos 60 pesquisadores tentam estabelecer diretrizes para tratamentos com a terapia gênica, no entanto, somente em meados dos anos 90 o seu uso na ciência foi autorizado. A terapia gênica em odontologia tem a capacidade de alterar e melhorar geneticamente, através de células-tronco em tecidos dentais e sua associação a vetores viras recombinados, protocolos terapêuticos contra enfermidades que não tem resposta aos tratamentos convencionais. Conclusão: A perspectiva da odontologia diante deste recurso tem sido positiva, principalmente no reestabelecimento e regeneração de tecidos em patologias pulpares, periodopatias, distúrbios ósseos, dores orofaciais entre outros. Sabe-se que esta terapia ainda requer muitas pesquisas, entretanto em um futuro próximo poderá ser um tratamento de primeira escolha e de forma segura nos ambientes hospitalares e ambulatoriais.

Termos de indexação: Terapia genética. Odontologia. Assistência odontológica.

\footnotetext{
$\boldsymbol{\nabla v} \boldsymbol{\nabla}$

${ }^{1}$ Centro Universitário FACOL, Departamento de Odontologia. Rua Pedro Ribeiro, 85, Universitário, 55612-275, Vitória de Santo Antão, PE, Brasil. Correspondence to: R BATISTA. E-mail: <regidaclea78@hotmail.com>.

2 Universidade Tiradentes, Departamento de Odontologia. Recife, PE, Brasil.

$\boldsymbol{\nabla} \mathbf{v}$

How to cite this article

Batista R, Arruda C, Tavares Y, Freitas T, Araújo T, Ramos A. Gene therapy and its applicability in Dentistry. RGO, Rev Gaúch Odontol. 2020;68:e2020000920180034. http://dx.doi.org/10.1590/1981-863720200000920180034
} 


\section{INTRODUCTION}

In 1850, austrian monk Gregor Mendel, in his experiments with peas, discovered and described genes and how they were arranged. In 1950, the double helix structure of the DNA was discovered by american biochemist James Watson and british biophysicist Francis Crick. Then, researchers discovered enzymes that separated the genes in a DNA molecule, uncovering the internal hereditary mechanism, which is extremely important in the world of science. Since then, medicine has benefited greatly from the discoveries in the area of genetics $[1,2]$.

With the diversity of microorganisms and bacterial proliferation, it is difficult to control pathologies and homeostasis in the oral environment. Odontology has been employing technological resources in treatments through gene therapy and recombinant DNA to repair the genome, manipulating and substituting defective genes for healthy genes and providing a certain relief of the symptoms or the cure of their ailment $[3,4]$.

Since the 19th century, genetics has been evolving in a more pronounced way. With human genome sequencing, science has obtained information that helped in the processes of seeking human health. With the development of the researches, genetic engineering has evolved with greater capability to determine etiopathogenesis, the processes, the disorders caused by gene alterations, the genes responsible and the actions in modulations of metabolic defects for the prevention and treatment of the pathologies [1,5-7].

\section{METHODS}

Table 1. Flowchart with methodological data applied to research.

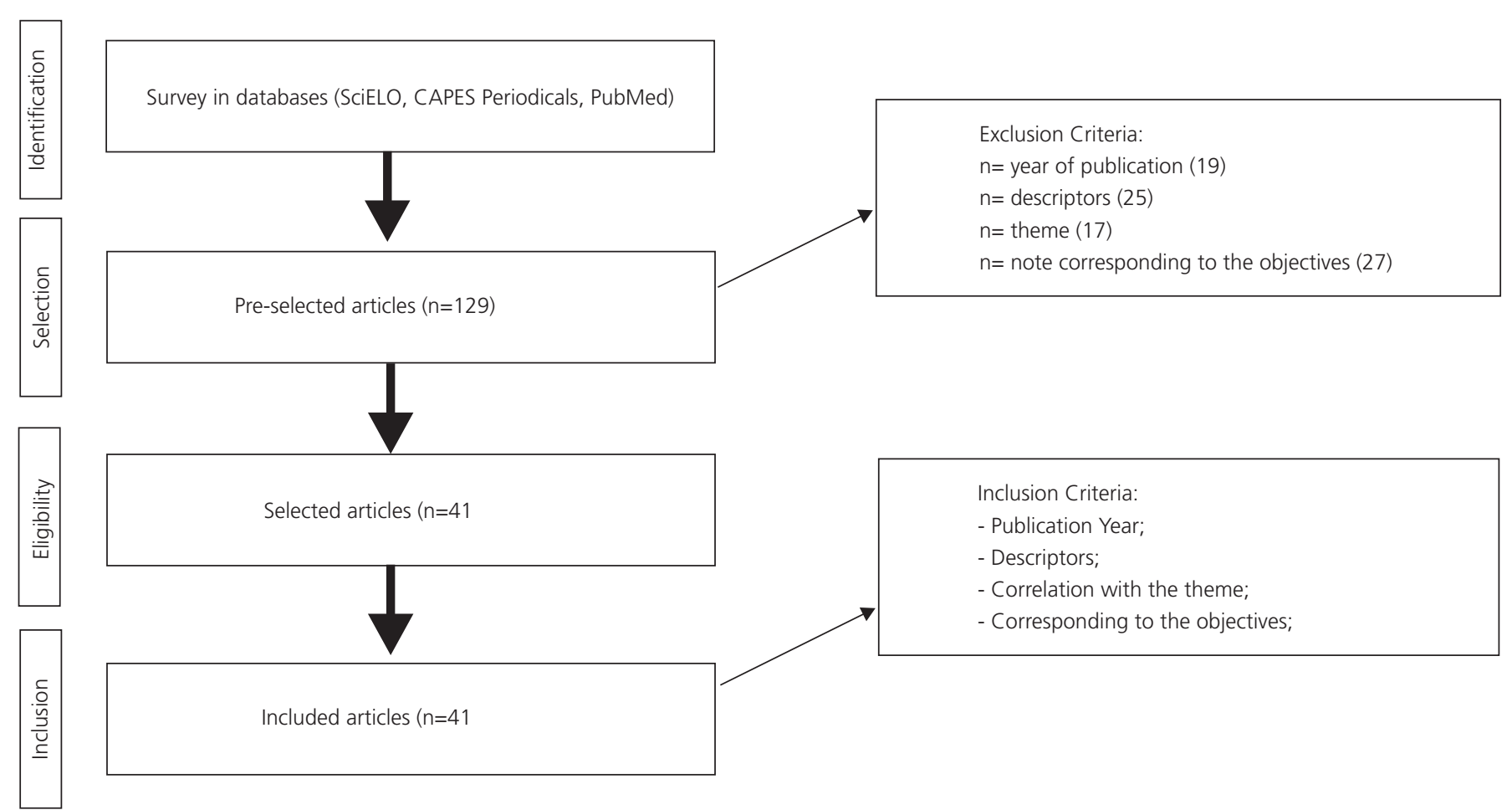

\section{RESULTS}

According to the selected publications, it was found that the use of gene therapy applied in several fields of odontology, aims to reestablish dentinary tissue, restoring its functions and homeostasis. This therapy presented satisfactory results, when compared to current therapies, and as such, presents itself as a promissory form of treatment to pathologies, which do not respond successfully to conventional therapies. 
Table 2. Applicability of the studies in Odontology.

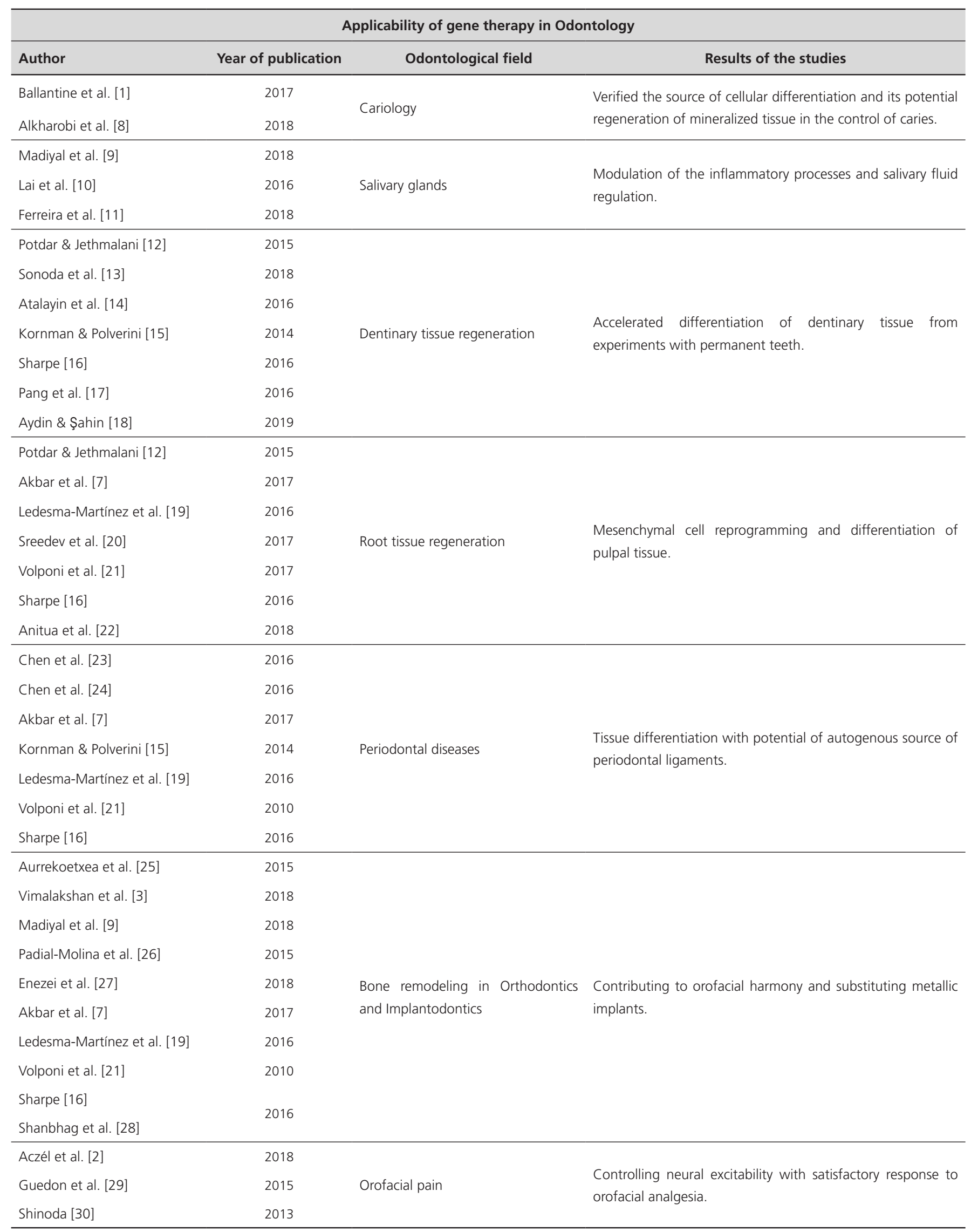




\section{DISCUSSION}

\section{The perspective of Gene Therapy}

Since the 1960s, researchers have attempted to create protocols for the usage of gene therapies, however only in 1990 the FDA (Food and Drug Administration) authorized the first protocol. In this protocol, two patients with primary immunodeficiency were submitted to genetic treatment and one of them was cured. Gene therapy is defined as the capability of genetic altering and bettering in the face of monogenic diseases, when conventional treatments are not able to obtain success. Genetic intervention can provide good results in the regeneration of damaged tissues, with beneficial physiopathological alterations to the patient. The clonal genetic cells of the oral epithelium are capable of differentiating in ameloblasts and dental structures of bioengineering. When prepared in mesenchymal dental tissues, they can be used as regulating mechanisms of genetic expression associated with amelogenin and ameloblastin proteins $[4,6,19,31-34]$.

\section{The role of vectors}

Vectors are codified viruses with the potential to enter cells and perform a carrier function, transporting nucleic acids DNA and RNA. This causes subsequent modifications in the usual expression of the host cell. Among the most studied vectors is the retrovirus from the family Lentivirus. Nowadays, it is among the most used, precisely because of its low chance to provide contraindications $[7,35,36]$

\section{Applicability in Odontology}

In 2006, the International Society For Cellular Therapy defined and authorized criteria on multipotent cells and their molecular processes in odontology. Stem cells offer regenerating potential in various tissues, with the ability to reestablish enamel, dentin, periodontal ligaments, pulp, dental papilla, periosteum, periapical follicles, salivary glands, bones and nerves. This granted bioengineering a field of activity and development to work with patients who have craniofacial alterations that require tissue regeneration due to trauma or pathologies. Thus, various branches of odontology can benefit from this technology $[5,7,15,16,19,21,34,36-38]$.

\section{Genetics X Kariology}

Dental caries are chronic, multifactorial diseases, caused by the formation of bacterial biofilm in susceptible teeth and is considered a public health concern. With the advent of the genome sequencing of the Streptococcus mutans bacterium, it is possible to analyse the functionality, influence and interaction in the formation of caries. When affected by caries, the dentinal tissues act in defense of their dental pulp, stimulating the formation of a hard mineralized tissue, in other words, a reactionary dentin, difficulting the destruction of the vascularised subjacent pulpar tissue Studies try to analyse if, when stimulated by these pluri and multipotent cells, the odontoblasts can be sources of differentiation with potential for regeneration of the mineralised tissues $[1,8]$.

\section{Correction of the salivary secretory glands}

Deficiency in the salivary secretory glands implicate in oral morbidities such as caries, gingivitis and periodontal diseases. People with autoimmune conditions such as Sjogren's Syndrome or who went through head and neck radiotherapy have their oral homeostasis compromised due to hyposalivation. Researches and treatments through genetic transcription showed beneficial modulatory effects, treating inflammatory processes and regulating the fluids of the secretory glands. Thus, high expectations guide the reestablishment of the oral homeostasis resulting from use of these new technologies $[9,10,11]$.

\section{The use of molecular biology in the regeneration of Dentinary Tissues}

For there to be regeneration of a specific type of tissue, a triad of stem cells, molecular induction for the tissue proliferation and a support structure is necessary. Researches were made using stem cells and it was discovered that stem cells from dental elements are much more potent, being able to differentiate into several types of craniofacial tissues. According to studies performed in permanent third molars, signs of induction and tissue proliferation could be observed. In a certain amount of time, these cells differentiate into others of odontoblastic tissue, that have similar morphology to the formation of dentin. The stem cells from the permanent teeth had their 
differentiation more accelerated than those of primary teeth, due to being more mature [12-16].

\section{Stem cells in the treatment of periodontal diseases}

Periodontal diseases are pathologies with a chronic inflammatory origin, which cause alterations to the supporting tissues, damaging the periodont. It is a great challenge to establish a new formation of periodontal ligaments, but studies indicate that the cells in the periodontal ligaments are progenitor cells, and, when stimulated, have regenerative and multipotential capacities. The ligament cells which were stimulated by gene therapy were isolated and cultivated with the intention to analyse their capabilities. Layers of stem cells designed to facilitate the cell implantation along an anchorage of fibril and acellular cement presented results of cellular differentiation into osteoblasts, cementoblasts, adipocytes and fibroblasts. In vivo studies demonstrated tissue regeneration, proving periodontal ligaments can be an autogenous source of great importance to assist in the regeneration of periodontal diseases $[7,15,16,19,21,23,24]$.

\section{On the regeneration of root tissues}

Injuries caused by pathologies on the root tissues have been a major concern in odontology. Studies into the reprogramming of mesenchymal cells and transduction with retroviruses show great efficiency in the reproduction and differentiation of pulpar tissues. These cells were put inside a root canal system along with biological modulators and with the induction of blood clotting, which signaled the formation of a cellular matrix, similar to the pulp, with vascularization and mineralised tissues such as dentin. There is still a substantial discussion to be had concerning this technology and the real possibility of reestablishing a necrotic pulpar tissue. More researches and analysis are necessary to confirm the indications until it is applied in clinical practice $[7,12,16,19,20,21]$.

\section{Gene therapy in bone remodeling, Implantodontics and Orthodontics}

Researches with tissue engineering and genetic therapy have been of major importance in concern to the treatment of morbidities and bone repair needs caused by trauma, pathologies and orthodontic movement needs. The cells that differentiate into osteoblasts and osteoclasts act inhibiting the mechanism of bone resorption. Thus, studies have assisted in the aesthetic and functional reestablishment in the area of bone remodeling. Treatments using recombinant human protein to fill alveoli post tooth extraction for the increasing of the alveolar ridge, and for the repair of bone resorption are more promising than traditional grafting (allograft, xenograft and aloplast). The gene BMP2, which is located in the chromosome 20p12, after transcription, forms a homodimeric protein with subunits of 114 amino acids, performing a regulatory and hematopoietic development function, with the differentiation of osteoblast, chondroblast, mineralization and bone remodeling cells. The continuity of these studies is still imperative due to the lack of consensus regarding the amount of protein necessary for the production of tissue, which can cause troubling changes, such as soft tissue edema, but the success of the technique with the assistance of genetic therapy is proven in the face of research. The cells from apical papilla from unerupted third molars are known as stems and differentiate into odontoblasts and adipocytes, and, along with stem cells are able to form a biological root to reestablish the orofacial harmony with an implant. These cells are similar to embrionary cells and would substitute a metal implant $[3,7,9,16,19,21,25,26]$.

\section{Gene therapy in the treatment of orofacial pain}

Orofacial pains are reported as acute or chronic and are responsible for changes in the quality of life of the individual, being considered a public health problem. Studies with gene therapy have assisted in the process of gene recombination. Molecules and enzymes are responsible for carrying anti-inflammatory cytokines mediated by transferences with vectors to specific regions of neurotransmitters in the central nervous system, controlling impulses and influxes related to neural excitability, which causes hiperalgesia. This study indicates that, in a short time span, there will be a satisfactory answer related to prolonged orofacial analgesia $[2,28,29]$.

\section{CONCLUSION}

The research on stem cells and genetic engineering, especially those using viral vectors are considerable, which 
assures the possibility of new alternatives for treatments and cure in the face of the need of reestablishment of oral health. It is known that more studies are still needed for gene therapy to be considered a first option treatment. However, with the analysis of all possible risks and benefits, it is possible to expect a promising future for the advance of these new gene technologies. Gene therapy is already a reality and odontology longs for its satisfactory results.

\section{Collaborators}

R Batista, C Arruda, Y Tavares, T Freitas and T Araújo, data acquisition, writing and evaluation of the article. A Ramos, article evaluation and guidance.

\section{REFERENCES}

1. Ballantine JL, Carlson JC, Ferreira Zandoná AG, Agler C, Zeldin LP, Rozier RG, et al. Exploring the genomic basis of early childhood caries: a pilot study. Int J Paediatr Dent. 2018;28(2):217-225. https://doi.org/10.1111/ipd.12344

2. Aczél T, Kun J, Szőke É, Rauch T, Junttila S, Gyenesei A, et al. Transcriptional alterations in the trigeminal ganglia, nucleus and peripheral blood mononuclear cells in a rat orofacial pain model. Front Mol Neurosci. 2018;11:219. https://doi. org/10.3389/fnmol.2018.00219

3. Vimalakshan I, Ajantha HB, Kumar MP. Applications of gene therapy in dentistry: a review. Drug Invention Today. 2018;10(6):969-975.

4. Lee JS, Somerman MJ. The Importance of Oral Health in Comprehensive Health Care. JAMA. 2018;320(4):339-340. doi:10.1001/jama.2017.19777

5. Stanko, P., Kaiserova, K., Altanerova, V., \& Altaner, C. Comparison of human mesenchymal stem cells derived from dental pulp, bone marrow, adipose tissue, and umbilical cord tissue by gene expression. Biomedical Papers. 2014;158(3):373-377. http://dx.doi.org/10.5507/bp.2013.078

6. La Noce $M$, Paino F, Spina A, Naddeo P, Montella R, Desiderio $V$, et al. Dental pulp stem cells: state of the art and suggestions for a true translation of research into therapy. J Dent. 2014;42(7):761-768. http://dx.doi.org/10.1016/j.jdent. 2014.02.018

7. Akbar A, Chatra L, Shenai P, Prabhu, Veena KM, Rachana V, et al. Stem cell therapy in Dentistry. WJPPS. 2017;6(4):1970-1981. http://dx.doi.org/10.20959/wjpps20174-9003

8. Alkharobi H, Beattie J, Meade J, Devine D, El-Gendy R. Dental pulp cells isolated from teeth with superficial caries retain an inflammatory phenotype and display an enhanced matrix mineralization potential. Front Physiol. 2017;8:244. https:// doi.org/10.3389/fphys.2017.00244

9. Madiyal A, Babu S, Bhat S, Hegde P, Shetty A. Applications of stem cells in dentistry: A review. Gulhane Med J 2018;60:26-29.
10. Lai Z, Yin H, Cabrera-Pérez J, Guimaro MC, Afione S, Michael DG, et al. Aquaporin gene therapy corrects Sjögren's syndrome phenotype in mice. Proc Natl Acad Sci U S A. 2016;113(20):5694-5699. https://doi.org/10.1073/pnas.160 1992113

11. Ferreira JNA, Zheng $C$, Lombaert IMA, Goldsmith CM, Cotrim AP, Symonds JM, et al. Neurturin gene therapy protects parasympathetic function to prevent irradiation-induced murine salivary gland hypofunction. Mol Ther Methods Clin Dev. 2018;9:172-180. https://doi.org/10.1016/j.omtm.2018. 02.008

12. Potdar PD, Jethmalani YD. Human dental pulp stem cells: applications in future regenerative medicine. World J Stem Cells. 2015;7(5):839. https://doi.org/10.4252/wjsc.v7.i5.839

13. Sonoda S, Mei YF, Atsuta I, Danjo A, Yamaza H, Hama S, et al. Exogenous nitric oxide stimulates the odontogenic differentiation of rat dental pulp stem cells. Scientific Rep. 2018;8(1):3419. https://doi.org/10.1038/s41598-018-21183-6

14. Atalayin C, Tezel H, Dagci Taner K, Yavasoglu NU, Oktem G. Medium modification with bone morphogenetic protein 2 addition for odontogenic differentiation. Braz Oral Res. 2016; 30(1):e20. https://doi.org/10.1590/1807-3107BOR-2016.vol30. 0020

15. Kornman KS, Polverini PJ. Clinical application of genetics to guide prevention and treatment of oral diseases. Clin Genet. 2014;86(1):44-49. https://doi.org/10.1111/cge12396

16. Sharpe PT. Dental mesenchymal stem cells. Development. 2016;143(13):2273-2280. https://doi.org/10.1242/dev.134189

17. Pang YW, Feng J, Daltoe F, Fatscher R, Gentleman E, Gentleman MM, et al. Perivascular Stem Cells at the Tip of Mouse Incisors Regulate Tissue Regeneration. J Bone Miner Res. 2016 Mar;31(3):514-23. https://doi.org/10.1002/jbmr. 2717

18. Aydin S, Şahin F. Stem cells derived from dental tissues. In: Turksen K. (eds) Cell biology and translational medicine. São Paulo: Springer; 2019.

19. Ledesma-Martínez E, Mendoza-Núñez VM, Santiago-Osorio E. Mesenchymal stem cells derived from dental pulp: a review. Stem Cells Int. 2016;4709572. http://dx.doi.org/10.1155/20 $16 / 4709572$

20. Sreedev CP, Karthick K, Mathew S, Iswarya Raju I. Regenerative endodontics: an overview. J Indian Acad Dental Spec Res. 2017;4(1):18. https://doi.org/10.4103/jiadsr.jiadsr_16_17

21. Volponi AA, Pang Y, Sharpe PT. Stem cell-based biological tooth repair and regeneration. Trends Cell Biol. 2010;20(12):715722. https://doi.org/10.1016/j.tcb.2010.09.012

22. Anitua E, Troya M, Zalduendo M. Progress in the use of dental pulp stem cells in regenerative medicine. Cytotherapy. 2018;20(4):479-498. https://doi.org/10.1016/j. jcyt.2017.12.011

23. Chen FM, Gao LN, Tian BM, Zhang XY, Zhang YJ, Dong GY, et al. Treatment of periodontal intrabony defects using autologous periodontal ligament stem cells: a randomized clinical trial. Stem Cell Res Ther. 2016;7(1):33. https://doi. org/10.1186/s13287-016-0288-1 
24. Chen W, Gao B, Hao L, Zhu G, Jules J, MacDougall MJ, et al. Gene therapy of periodontal disease by AAV-shRNA silencing of Cathepsin $\mathrm{K}$ by inhibiting inflammation in periodontal lesion area. J Periodontal Res. 2016 Oct;51(5):647-60. https:// doi.org/10.1111/jre.12345

25. Aurrekoetxea M, Garcia-Gallastegui P, Irastorza I, Luzuriaga J, Uribe-Etxebarria $V$, Unda $F$, et al. Dental pulp stem cells as a multifaceted tool for bioengineering and the regeneration of craniomaxillofacial tissues. Front Physiol. 2015 Oct 16;6:289. https://doi.org/10.3389/fphys.2015.00289.

26. Padial-Molina M, O’Valle F, Lanis A, Mesa F, Dohan Ehrenfest DM, Wang HL et al. Clinical application of mesenchymal stem cells and novel supportive therapies for oral bone regeneration. BioMed Res Int. 2015:341327. https://doi.org/10. $1155 / 2015 / 341327$

27. Enezei HH, Ahmad A, Takeuchi K, Suzuki J, Khamis MF, Razak NHA, et al. Osteoinductive Activity of Bone Scaffold Bioceramic Companied with Control Release of VEGF Protein Treated Dental stem cells as A New Concept for Bone Regeneration: Part II. J Hard Tissue Biol. 2018;27(1):69-78. https://doi.org/10.2485/jhtb.27.69

28. Shanbhag S, Suliman S, Pandis N, Stavropoulos A, Sanz M, Mustafa K. Cell therapy for orofacial bone regeneration: A systematic review and meta-analysis. J Clin Periodontol. 2019;46 Suppl 21:162-182. https://doi.org/10.1111/jcpe.130 49

29. Guedon JMG, Wu S, Zheng X, Churchill CC, Glorioso JC, Liu $\mathrm{CH}$. Current gene therapy using viral vectors for chronic pain. Mol Pain. 2015;11:27. https://doi.org/10.1186/s12990-015-0 018-1

30. Shinoda M, Iwata K. Neural communication in the trigeminal ganglion contributes to ectopic orofacial pain. J Oral Biosci. 2013;55:165-168. https://doi.org/10.1016/j.job.2013.06.003

31. Bloch-Zupan A. Hypophosphatasia: diagnosis and clinical signs - a dental surgeon perspective. Int J Paediatr Dent. 2016;26(6):426-438. https://doi.org/10.1111/ipd.12232
32. Saito MT, Silvério KG, Casati MZ, Sallum EA, Nociti FH Jr. Toothderived stem cells: Update and perspectives. World J Stem Cells. 2015 Mar 26;7(2):399-407. https://doi.org/10.4252/ wjsc.v7.i2.399.

33. Takahashi C, Yoshida H, Komine A, Nakao K, Tsuji T, Tomooka Y. Newly established cell lines from mouse oral epithelium regenerate teeth when combined with dental mesenchyme. In Vitro Cell Dev Biol Anim. 2010;46(5):457-468. https://doi. org/10.1007/s11626-009-9265-7

34. An Z, Sabalic M, Bloomquist RF, Fowler TE, Streelman T, Sharpe PT. A quiescent cell population replenishes mesenchymal stem cells to drive accelerated growth in mouse incisors. Nature Communications. 2018;9(1):378. https://doi.org/10.1038/s414 67-017-02785-6

35. Milone MC, O’Doherty U. Clinical use of lentiviral vectors. Leukemia. 2018;32(7):1529-1541. https://doi.org/10.1038/ s41375-018-0106-0

36. Murlidharan G, Samulski RJ, Asokan A. Biology of adenoassociated viral vectors in the central nervous system. Front Mol Neurosci. 2014;7:76. https://doi.org/10.3389/fnmol.2014. 00076

37. Gong T, Heng BC, Lo EC, Zhang C. Current advance and future prospects of tissue engineering approach to dentin/pulp regenerative therapy. Stem Cells Int. 2016;2016:9204574. https://doi.org/10.1155/2016/9204574

38. Caicedo CJ, Villareal MP. Avances en bioingeniería dental y su aplicación en ortodoncia y ortopedia dentofacial: Una revisión de literatura. Rev Estomat Salud. 2017;25(1):32-42.

Received on: 5/11/2018

Final version resubmitted on: 11/4/2019

Approved on: 15/4/2019 